\title{
The Influence of Capital Loans Composition on Housing Project Cash Flow in Tabanan by Using @. Risk Program
}

\author{
Ni Komang Armaeni ${ }^{1}$, I Ketut Nudja S ${ }^{2}$, Anak Agung Sagung Dewi Rahadiani ${ }^{3}$ \\ \{nikmarmaeni1978@gmail.com¹,nudja54@gmail.com²,dewi_rahadiani@yahoo.com³ ${ }^{3}$ \} \\ Warmadewa University, Department of Civil Engineering, Denpasar-Bali, Indonesia ${ }^{123}$
}

\begin{abstract}
One of the failure causes of an investment in the housing sector is caused by the incomplete analysis of the composition of loan capital in housing investment. The situation is interesting thing to observe. The research in Tabanan Regency aims to find out the effect of the composition of loan capital on housing investment risks, especially houses of type 36 to type 70 . The method used was inferential method, which is a method for analyzing data from a sample and then making inferences about the population. While the risk analysis was carried out quantitatively with the @ Risk program. The results of the analysis on the distribution diagram show that the larger the loan capital the smaller the probability of the value of NPV $>0$ and the value of $\mathrm{BCR}>1$ which means that the smaller the chance to earn greater profits.
\end{abstract}

Keywords: housing project investment, project cash flow, @risk program

\section{Introduction}

The pattern of calculating investments manually requires a relatively long time. The existence of cash flow model that is briefly able to provide an idea of the development of our investment in a certain period of time and will greatly facilitate the decision making whether or not the investment is implemented and it can consider the matters relating to risks that might occur seen from investment funding.

Risk and uncertainty are two key characteristics of business and government problems that must be understood to be able to make decisions [1]. Risk analysis can be done both qualitatively and quantitatively. Qualitative risk analysis focuses on identification and risk assessment while quantitative analysis focuses on evaluating probabilities of risk occurrence, generally involves more complex analysis techniques using computer programs [2].

In the process of assessing the feasibility of investing from a financial aspect, the conventional approach taken is to analyze the estimates of outgoing and incoming cash flow during the period of the project or investment. Cash flow provides an overview of the amount of funds available at any time that can be used for the company's operational needs [3].

To determine the proposed investment project to be accepted or rejected, the proposed investment project must meet the project assessment. In this case, the valuation methods often used to assess project proposals are the NPV and BCR method. If NPV is positive, it means that the funds invested in the project can generate PV cash flow that is higher than the initial PV investment. Thus, an investment project proposal is accepted if the NPV is zero. While the 
$\mathrm{BCR}$ method will provide guidance if $\mathrm{BCR}>1$ then the project proposal is accepted and if $\mathrm{BCR}<1$ then the project proposal is rejected [4].

Based on market segments that are targeted in real estate investment in Indonesia, in general real estate investment can be divided into three groups, namely: simple class real estate, middle class real estate and high-end real estate. [5]

Analysis of the probability value and impact of the risk of investment in upper middle class residential real estate in Bandung with qualitative risk analysis shows high risk in investment in the cases of land acquisition and compensation, certainty of funds for investment continuity, market competition, low labor productivity, sources and financing structures used, additional/less work, complicated negotiations, bloated operating costs, inefficient government bureaucratic processes, availability utility system around the site, and land and building certification [6].

The investment financing analysis of the Green Pakis Regency Malang housing project states that a combination of capital of $30 \%$ own capital and $70 \%$ of loans results the smallest cost of capital, that is $11.1 \%$, and generates positive leverage with the largest ratio of ROE and ROR which is equal to 1.98 which is the lightest composition of financing and has the lowest rate of return [7].

The research "A multi criteria decision analysis for reinvestment action portfolio selection problem in an Indonesian real estate company" states that financial feasibility studies are very important in making decisions. The research provides a better assessment of objectivity in assessing the financial performance of a real estate project and says that Monte Carlo simulation is an effective and efficient tool for managing uncertainty in decision making [8].

Research on optimal cash flow analysis at a housing construction project contractor concludes that the cash flow is influenced by the payment term and amount of down payment. For this reason, it is necessary to consider increasing the number of advances for each payer [9].

Risk Analysis Modeling Cash Flow Research in the middle to upper class Housing Investment Project in Badung Regency With the @ Risk Program (Case Study on Small to Medium Type Housing Projects) shows that there are four most decisive variables, namely land area and land price per $\mathrm{m}^{2}$ giving a negative correlation, house price type 45/100 and house price type 54/100 provide a positive correlation [10].

A publication on the International Seminar of the Faculty of Engineering Warmadewa University " 1 st Warmadewa University International Conference on Architecture dan Civil Engineering (WUICACE)" that was held in October 2017 gives an illustration that cash flow with the composition of capital: $40 \%$ of own capital and $60 \%$ of loan capital has the greatest probability value of NPV $>0$ and $\mathrm{BCR}>1$, that is $0.1 \%$ and $37.1 \%$. This means that this cash flow model has the greatest chance of gaining greater profits compared to other models [11]. Therefore, it is necessary to continue the research that analyzes the effect of loan capital on the cash flow of housing investment in each regency. One of the regencies is Tabanan Regency by adding data to the data in 2017.

\section{Methodology}

The research method used is inferential method, which is a method for analyzing data from a sample to then make conclusions about the population [12]. It means the results of the 
sample are applied to all populations or in other words can be generalized so this method aims to draw conclusions from the results of the study.

The preparation in the implementation of data collection and initial survey was a review of government policies relating to investment in the construction of lower middle-class housing in Indonesia and especially in Tabanan Regency by making questionnaires for developers about financial planning and investments, making work schedules, distributing questionnaires, and collecting them back.

The complexity of the analysis that must be done, then in this quantitative risk analysis the process is assisted by using a computer program that is the @risk program.

The cash flow models / scenarios created are Model 1: 50\% loan capital and Model 2: $80 \%$ loan capital. The model of cash flow investment in lower middle-class housing is then analyzed with the @risk program.

\section{Result and Discussion}

Sampling of this research data was carried out by census by distributing questionnaires as many as 40 copies in Tabanan Regency. Only 30 of the 40 questionnaires distributed on the 2015-2017 middle-class housing projects were collected (see Table 1).

Table 1. Questionnaire Collected

\begin{tabular}{clcc} 
No. & District Location & $\begin{array}{c}\text { The number of } \\
\text { Questionnaires } \\
\text { distributed }\end{array}$ & $\begin{array}{c}\text { The number of } \\
\text { Questionnaires collected }\end{array}$ \\
\hline 1. & Tabanan & 40 & 30 \\
\hline & Percentage & $100 \%$ & $75 \%$ \\
\hline
\end{tabular}

Data analysis in this study uses an estimation method that is related to middle- and lowerclass housing investment, especially financial aspects. Based on the results of the literature study, the variables of the financial aspects include the costs to be incurred, estimated income, taxes imposed, sources of financing, and selling prices.

All of these variables will be contained in a cash flow of housing project for middle to lower class. In the final stage of the financial aspect analysis, the amount of profitability will be obtained which is the basis for consideration of a middle to lower class housing investment. In the final stage of the financial aspect analysis, the amount of profitability will be obtained which is the basis for consideration of a middle to lower class housing investment.

The probability distribution value will be searched for on data used in the cash flow using the @risk program that can be done in three ways based on the condition of the data, that is RiskNormal $(\mu, \sigma)$; RiskUniform(min,max) dan RiskTriang(min,most likely,max).

The data that is sought for the probability distribution value is data that will be used in cash flow, as in Table 2

Table 2. The supporting data of Cash Flow

\begin{tabular}{llcc|c|}
\hline No. & Data Description & Unit & $\begin{array}{c}\text { Value of } \\
\text { Probability } \\
\text { Distribution }\end{array}$ & $\begin{array}{c}\text { Types of } \\
\text { Distribution }\end{array}$ \\
\hline $1 . \quad$ Land acquitted & $\mathrm{m}^{2}$ & 1648,5 & Normal \\
\hline
\end{tabular}




\begin{tabular}{llccc}
\hline 2. & The length of time of land acquisition & month & 7 & Triangle \\
\hline 3. & The land area is used as fasos / fasum & $\%$ & 25 & Triangle \\
\hline & $\begin{array}{l}\text { Number of units built according } \\
\text { existing type }\end{array}$ & & & \\
4. & $-\quad$ Type 36/100 & Unit & 5 & Triangle \\
& $-\quad$ Type 45/100 & & 2 & Triangle \\
& $-\quad$ Type 54/100 & month & 2 & Normal \\
\hline 5. & Time to design a house & month & 4 & Triangle \\
\hline 6. & Time to build a house for each unit & month & 10 & Normal \\
\hline 7. & Time required for marketing & & & \\
\hline
\end{tabular}

House price per unit according to the type

\begin{tabular}{|c|c|c|c|}
\hline 8. & $\begin{array}{ll}- & \text { Type } 36 / 100 \\
- & \text { Type } 45 / 100 \\
- & \text { Type } 54 / 100\end{array}$ & rupiah & $\begin{array}{l}393.809 .52 \\
470.615 .38 \\
523.000 .00\end{array}$ \\
\hline
\end{tabular}

\begin{tabular}{|c|c|c|c|c|}
\hline 9. & Number of units sold each month & Unit/month & 3 & Triangle \\
\hline 10. & Time used to manage permissions & month & 4 & Triangle \\
\hline 11. & Mortgage Advance & $\%$ & 30 & Uniform \\
\hline 12. & Interest Rate Credit & $\%$ & 13,6 & Triangle \\
\hline 13. & Time for disbursement of mortgage funds & month & 5 & Normal \\
\hline 14. & Design and Supervision Costs & rupiah & 35.082 .000 & Normal \\
\hline 15. & Age of Investment & month & 18 & Normal \\
\hline 16. & 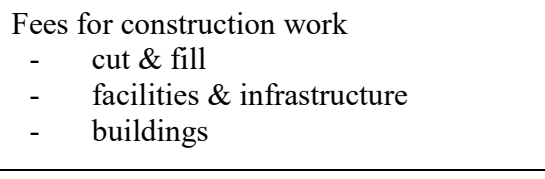 & Rupiah $/ \mathrm{m}^{3}$ & $\begin{array}{c}90.000 \\
55.000 \\
3.016 .667 \\
\end{array}$ & $\begin{array}{l}\text { Normal } \\
\text { Normal } \\
\text { Normal }\end{array}$ \\
\hline 17. & $\begin{array}{l}\text { Non Construction Cost } \\
\text { Land acquisition } \\
\text { Entry Exemption } \\
\text { Permissions } \\
\text { - Lot Permits } \\
\text { - IMB type } 36 / 100 \\
\text { - IMB type } 45 / 100 \\
\text { - IMB type } 54 / 200 \\
\text { Marketing } \\
\text { Sales Fee } \\
\text { Tax } \\
\text { Contributions to village areas } \\
\text { Over Head } \\
\text { Notary fees } \\
\text { Office Operational Cost }\end{array}$ & $\begin{array}{c}\text { Rupiah/plots } \\
\text { Rupiah/unit } \\
\text { Rupiah/unit } \\
\text { Rupiah/unit } \\
\text { Rupiah } \\
\% \text { / unit } \\
\% \\
\text { Rupiah/lot } \\
\text { Rupiah/unit } \\
\text { Rupiah/lot } \\
\text { Rupiah/month }\end{array}$ & $\begin{array}{c}1.390 .000 \\
2.583 .333 \\
3.066 .666 \\
3.100 .000 \\
\\
21.333 .333 \\
4,63 \\
10 \\
2.565 .000 \\
2.185 .185 \\
4.586 .206 \\
20.433 .333 \\
\end{array}$ & $\begin{array}{l}\text { Triangle } \\
\text { Normal } \\
\text { Normal } \\
\text { Normal } \\
\text { Normal } \\
\text { Normal } \\
\text { Normal }\end{array}$ \\
\hline
\end{tabular}


The data that has been sought for its distribution value can be used as data in the middlelow housing cash flow project. The cash flow of the middle to lower class housing project consists of three parts, namely: cash in, cash out) and balance.

In compiling cash flow, assumptions are needed in the distribution of data in cash flow. The assumptions are adjusted to the cash flow model that will be created. After establishing these assumptions, then the data is processed in cash flow. The cash flow created is controlled by the Net Present Value (NPV) and Benefit Cost Ratio (BCR). If it is in accordance with the investment assessment, then the NPV and BCR values are simulated by the @risk program to determine the risk of the probability and sensitivity of each of these assessments.

The following are the results obtained from the cash flow of each model, as shown in Table 3 .

Table 3. Investment Valuation Control

\begin{tabular}{ccc}
\hline MODEL OF & INVESTMENT ASSESSMENT CONTROLS \\
CASH FLOW & NPV & BCR \\
\hline Model 1 & $3,193,303,469.73$ & 1.314 \\
\hline Model 2 & $1,126,444,036.33$ & 1.096 \\
\hline
\end{tabular}

From the table above shows that all models meet the control requirements for housing investment valuation (NPV $>0$ and BCR $>1$ ). Simulations on the @Risk program will display charts / diagrams according to the cash flow model created. The diagram chosen to analyze the investment assessment criteria from each cash flow made is a distribution diagram. In this diagram shows the magnitude of the probability of each investment criteria (net present valueNPV and benefit cost ratio-BCR).

The following is a figure of the distribution diagram of each cash flow model analyzed by the@Risk program:

\subsection{Cash Flow Model 1}

\subsubsection{NPV}

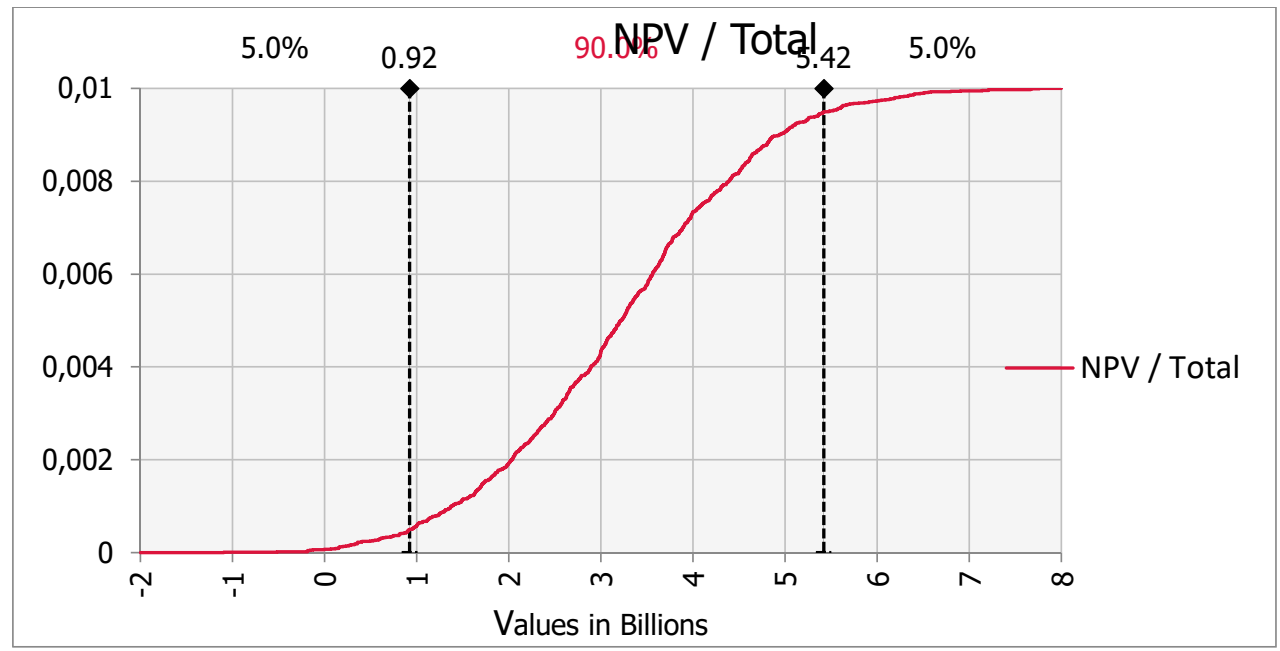

Fig.1 NPV Distribution of Cash Flow Model 1 
The diagram above shows that investment with a composition of capital: $50 \%$ of loan capital has a large probability of NPV $\leq 0$ that is $0.8 \%$ and the probability of NPV $>0$ that is $99.2 \%$.

\subsubsection{BCR}

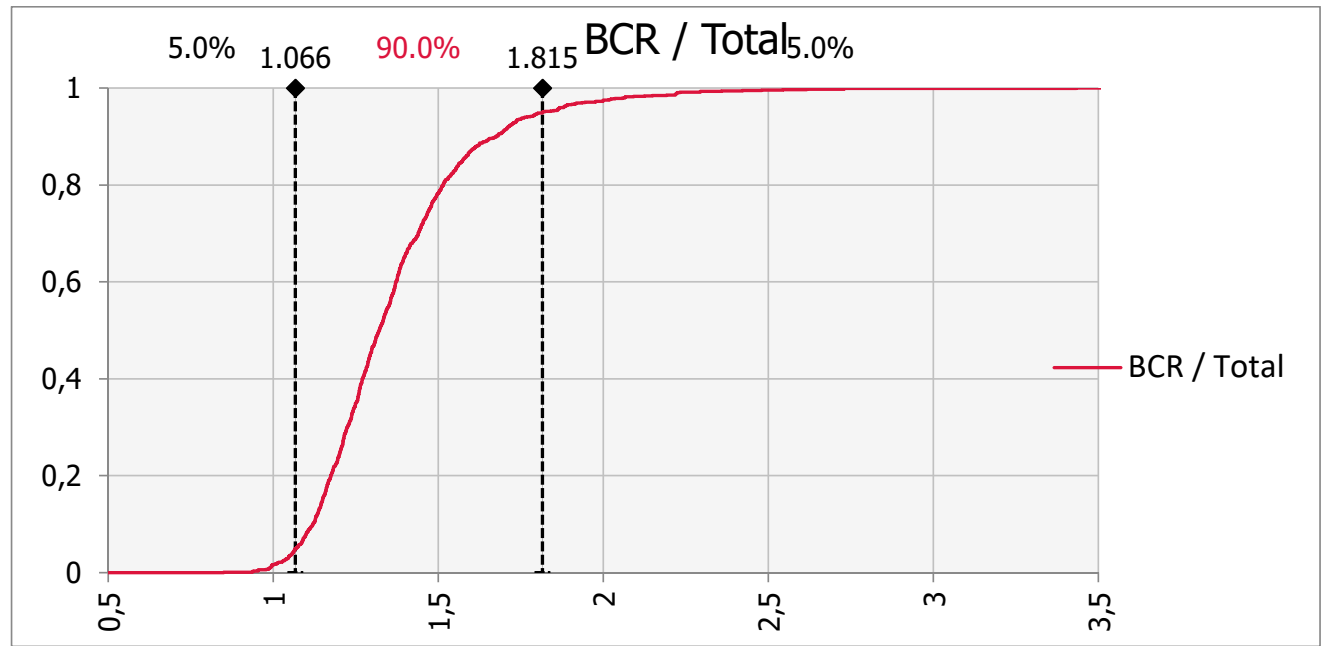

Fig.2 BCR Distribution of Cash Flow Model 1

The diagram above shows that investment with a capital composition: $50 \%$ of loan capital has a large probability of $\mathrm{BCR} \leq 1$ that is $0 \%$ and the probability of $\mathrm{BCR}>1$ that is $100 \%$.

\subsection{Cash Flow Model 2}

3.2.1. NPV

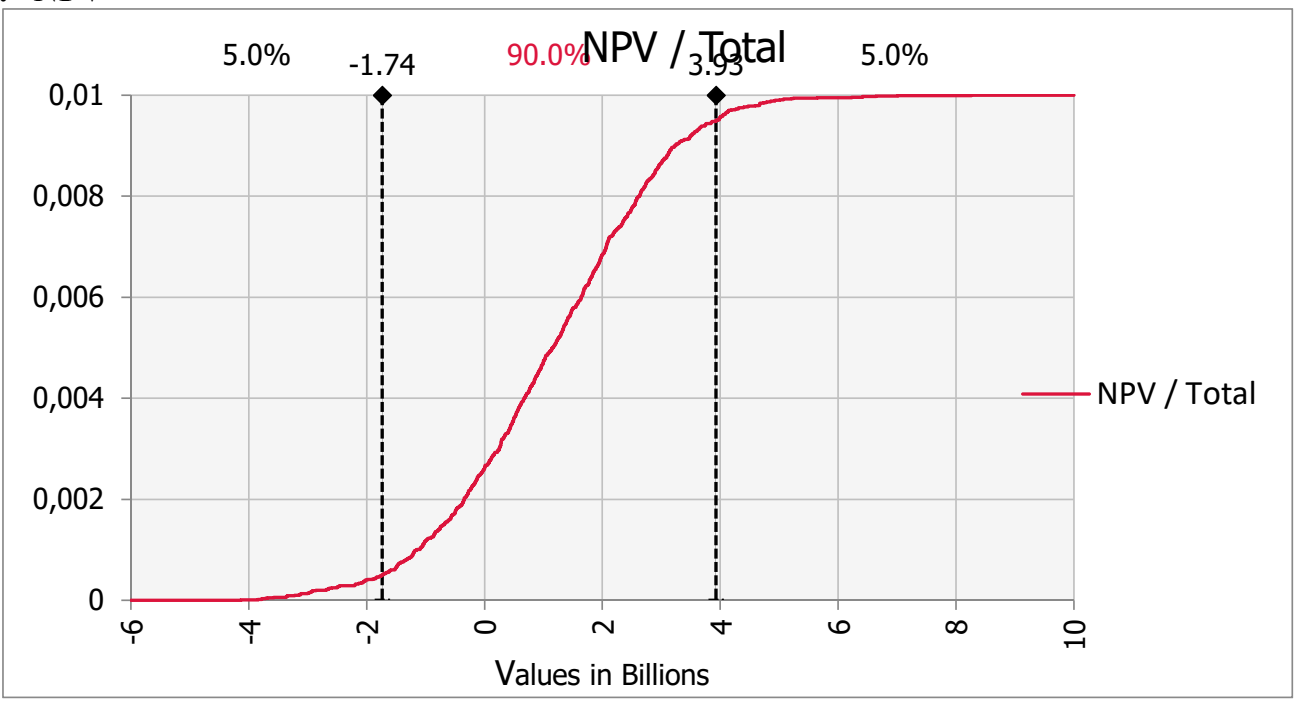

Fig.3 NPV Distribution of Cash Flow Model 2 


\subsubsection{BCR}

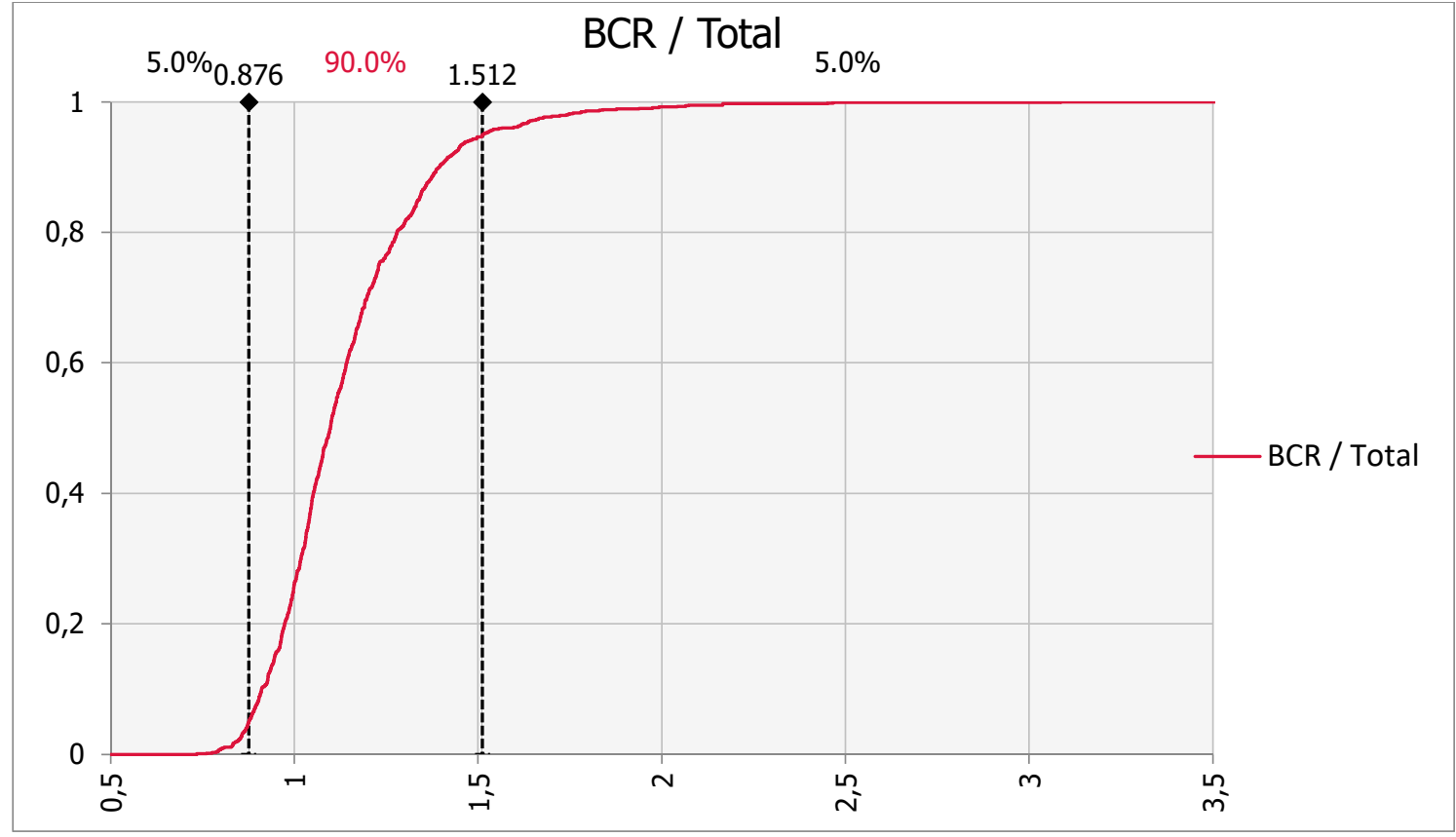

Fig.4 BCR Distribution of Cash Flow Model 2

The distribution diagram of the cash flow model above illustrates that each model has a different probability of NPV and BCR so each model of cash flow has different opportunities to obtain a large profit.

The following is an analysis of the recapitulation of the Distribution Diagram for the NPV and BCR of each cash flow model shown in Table 4 Probability Value of NPV and BCR

Table 4. Probability Values of NPV and BCR

\begin{tabular}{ccccc}
\hline & \multicolumn{4}{c}{ Investment Indicator } \\
Model of Cash Flow & $\begin{array}{c}\text { Probability NPV } \\
\leq 0\end{array}$ & $\begin{array}{c}\text { Probability NPV } \\
>0\end{array}$ & $\begin{array}{c}\text { Probability BCR } \\
\leq 1\end{array}$ & $\begin{array}{c}\text { Probability BCR } \\
>1\end{array}$ \\
\hline $\begin{array}{c}\text { Cash Flow Model } 1 \\
(50 \%: 50 \%)\end{array}$ & $0,8 \%$ & $99,2 \%$ & $0 \%$ & $100 \%$ \\
\hline $\begin{array}{c}\text { Cash Flow Model } 2 \\
(20 \%: 80 \%)\end{array}$ & $26,3 \%$ & $73,7 \%$ & $0 \%$ & $100 \%$ \\
\hline
\end{tabular}

The table above illustrates that cash flow model 1 (investment with the composition of capital: $50 \%$ of own capital and $50 \%$ of loan capital) has the greatest probability value of NPV $>0$ and BCR $>1$, that is $99.2 \%$ and $100 \%$. This means that this cash flow model has the greatest opportunity to obtain greater profits compared to model 2 . 


\section{Conclusion}

The results of the analysis with the Distribution diagram illustrate that cash flow model 1 (investment with the composition of capital: $50 \%$ of own capital and $50 \%$ of loan capital) has the greatest probability value of NPV $>0$ and $\mathrm{BCR}>1$, that is $99.2 \%$ and $100 \%$. This means that cash flow model 1 has the greatest opportunity to obtain greater profits. Therefore, it can be concluded that the composition of capital greatly affects the size of the opportunity to obtain greater profits. This can be used as an investor's consideration in developing middlelow housing projects in Tabanan Regency.

\section{Acknowledgments}

The author would like to thank the Warmadewa University Research Institute for providing research grants. Thanks also to express out our appreciation to Real Estate Indonesia (REI) for sharing their valuable member list that we used to find the financial report which we analysis in this particular research

\section{References}

[1] Vose, D.: Risk Analysis. John Willey \& Sons Ltd, West Sussex (1996)

[2] Flanagan, R., \& Norman, G.: Risk Management and Construction. Blackwell Science, Australia (1993)

[3] Soeharto, I.: Manajemen Poyek Dari Konseptual Sampai Operasional. Erlangga, Jakarta (1995)

[4] Halim, A.: Analisis Investasi. PT Salemba Emban Patria, Jakarta (2005)

[5] P. Simanungkalit, Bisnis Properti. Jakarta: Pusat Studi Propert Indonesia, 2006.

[6] Lesmana, I.G.: Analisis Nilai Probabiltas dan Dampak dari Resiko Investasi Perumahan kelas menengah keatas Kelas Menengah ke Atas di Kota Bandung. Tesis. Universitas Katolik Parahyangan, Bandung (2004)

[7] Utomo, M.: Analisa Pembiayaan Investasi Proyek Perumahan kelas menengah keatas Green Pakis Regency Malang. Jurnal Teknik Pomits. Vol. 3(2), pp. 67-7 (2014)

[8] Ronyastra, I.M., Gunarta, I.K., \& Ciptomulyono, U.: A Multi Criteria Decision Analysis for Reinvestment Action Portfolio Selection Problem in an Indonesia Perumahan kelas menengah keatas Company. Procedia Manufacturing. Vol. 4. pp. 558 - 567 (2015)

[9] Tolangi, M.F., Rantung, J.P., Langi, J.E.C., \& Sibi, M.: Analisis Cash Flow Optimal pada Kontraktor Proyek Pembangunan Perumahan. Jurnal Sipil Statik. Vol. 1(1). pp. 60-64 (2012)

[10] Armaeni, N.K., Widanan, I.W., \& Sriastuti, D.A.N.: Aalisis Risiko Pemodelan Cash Flow Proyek Investasi Real Estate di Kabupaten Badung dengan Program@Risk Paduraksa. Jurnal Teknik Sipil. Vol. 5( 2). pp. 46-62 (2017)

[11] Armaeni, N.K., Mustika, N.W.M.., \& Rahadiani, A.A.S.D.: The Influence of Capital Composition to Real Estate Investment Risk in Gianyar by Using @Risk Program. Proceeding International Conference The 1st Warmadewa University International Conference On Architecture And Civil Engineering (2017)

[12] Kountur, R.: Statistik Praktis. PPM, Jakarta (2006) 